\title{
Radio Komunitas dan Potensi Konflik Horizontal
}

\author{
Lukas Deni Setiawan \\ Mahasiswa Pascasarjana Ilmu Komunikasi Universitas Gadjah Mada
}

\begin{abstract}
Abstrak
Multikulturalisme membawa berkah sekaligus potensi negatif. Berkahnya adalah pedoman untuk menghargai identitas dan hak setiap kelompok masyarakat. Potensi negatifnya muncul manakala penghargaan tersebut dimaknai sebagai legitimasi terhadap arogansi kelompok masyarakat tertentu. Dilema masyarakat multikultur ini mengiringi tumbuh-kembangnya Radio Komunitas di Indonesia. Di satu sisi, masyarakat sangat merespons positif kehadirannya sebagai media pengeras suara akar rumput. Namun di sisi lain, kondisi ini memancing sebagian kelompok masyarakat untuk menyebarluaskan ideologi kelompoknya melalui penggunaan frekuensi milik publik. Apabila sisi lain ini lebih mengemuka, potensi konflik antar kelompok pun semakin menguat.
\end{abstract}

Kata Kunci: Multikulturalisme, Radio Komunitas, Potensi Konflik

\begin{abstract}
Multiculturalism brings blessing and a negative potential. Blessed are the guidelines to respect the identity and rights of every community. Negative potential appears when the award is meant as a legitimacy to the arrogance of certain communities. This multicultural society dilemma accompany growth and development of Community Radio in Indonesia. On the one hand, the community is responding positively presence as a grassroots media speaker. But on the other hand, these conditions led some groups to disseminate the ideology of the group through the use of publicly owned frequencies. If the other side is more prominent, the potential for conflict between groups also became stronger.
\end{abstract}

Keywords: Multiculturalism, Community Radio, Potential for Conflict

\section{Pendahuluan}

Indonesia, selayaknya negara-negara lain yang memilih sistem demokrasi sebagai filsafat sosialnya, mengangankan Radio Komunitas dapat menjadi salah satu jalan keluar tersumbatnya jalur diversity of content dan diversity of ownership media. Angan-angan ini muncul sebagai reaksi atas terjebaknya kehidupan bermedia di Indonesia dalam pusaran konglomerasi bisnis. Pusaran ini memusat pada persaingan segelintir pemilik media kelas kakap yang notabene adalah pembangun emporium kapital lintas sektor. Persaingan yang meruncing tersebut menyebabkan orientasi isi media terpatri pada perhitungan untung-rugi kas perusahaan. Hal ini berkelindan dengan kuatnya ketergantungan media massa dan pengiklan pada perhitungan share dan rating.

Namun, jalan keluar tersebut tidak tanpa halangan. Radio Komunitas mempunyai kompleksitas masalahnya sendiri. Ia yang diangankan dapat memuat suara akar rumput-yang hilang 
terseret arus deras persaingan bisnis media komersial-dan memunculkan keberagaman cara pandang terhadap berbagai masalah lokal, justru berpotensi memporakporandakannya. Contoh nyata tergambar pada kasus Radio Idza'atul Khoir di Ponorogo, Jawa Timur, yang diprotes oleh sekitar 300 pengunjuk rasa dari setidaknya 10 elemen masyarakat yang tergabung dalam Aliansi Masyarakat Anti Radikalisme (AMAR). Radio tersebut didakwa telah mengumandangkan materi siaran yang merendahkan sebagian elemen masyarakat dan mengarah pada radikalisme ajaran agama tertentu. Hal ini, oleh para pemrotes, disinyalir dapat menimbulkan perpecahan dan konflik horizontal (www.seputar-indonesia.com).

Kasus tersebut mengingatkan kita setidaknya pada dua hal. Pertama, Radio Komunitas merebak di atas tanah-air yang majemuk dan lingkungan yang dihidupi oleh sekian ragam suku, agama, ras dan golongan. Oleh karena itu, interaksi yang terjadi sangat rentan akan konflik yang terpicu oleh kepentingan masingmasing golongan. Kedua, (oleh karena hal yang pertama) Radio Komunitas tidak diperkenankan berorientasi pada kepentingan propaganda bagi kelompok atau golongan tertentu (Pasal 21 Ayat 3 Bagian c Undang-Undang Republik Indonesia Nomor 32 Tahun 2002 tentang Penyiaran). Hal ini mengisyaratkan bahwa Radio Komunitas, alih-alih dipakai sebagai ajang dialog akar rumput, justru rentan dimanfaatkan oleh golongan atau kelompok tertentu yang berpotensi memecah-belah harmoni interaksi yang coba dibangun oleh sekian ragam kultur yang ada tersebut.

Fenomena di atas menggiring tulisan ini untuk mendiskusikan setidaknya dua hal. Pertama, bagaimana perkembangan Radio Komunitas dalam masyarakat multikultur seperti di Indonesia? Kedua, sejauh mana Radio Komunitas dapat memicu terjadinya konflik horizontal berdasar Suku, Agama, Ras dan Antar golongan (SARA)? Untuk mengawali diskusi mengenai hal tersebut, bolehlah kiranya kita menelusuri kembali hakekat multikulturisme dan radio komunitas hingga perkembangan mutakhirnya saat ini.

\section{Multiculturalism}

Salah satu pengembang gagasan multikulturalisme adalah Bhikhu Parekh (sekarang banyak dikutip). Menurutnya, Multikulturalisme mengacu pada relationship antara kelompok-kelompok budaya yang berbeda yang hidup di masyarakat; dan oleh karenanya, gagasan ini tidak secara spesifik menawarkan pembelaan terhadap kaum minoritas (Parekh, 2000). Lebih jauh, Parekh merekomendasikan bahwa multikulturalisme bukanlah sebuah doktrin politik dengan muatan programatik, tidak pula sebagai aliran falsafah dengan teori yang khas tentang tempat manusia di dunia, melainkan lebih sebagai sebuah perspektif atau cara melihat kehidupan manusia (Budiman, 2007). Walaupun demikian, ia menambahkan pula bahwa praktik multikulturalisme tersebut akan lebih mudah disimak dan dipahami dalam konteks kebijakan politik suatu negara.

Kanada adalah salah satu contoh menarik dalam hal ini. Negara tersebut memunculkan "sosok" multikulturalisme tidak hanya dalam wujud wacana. Ia adalahnegarapertamadiantarakomunitas internasional yang mengemukakan multikulturalisme sebagai gerakan sosial, bahkan pemerintahnya telah mengangkat dan menerapkannya sebagai kebijakan publik. Dengan demikian, Kanada telah berikhtiar untuk menegaskan dan menegakkan nilai dan harkat martabat 
warga negaranya, tanpa pandang bulu terhadap latar belakang bahasa, asalmuasal kesukuan, kedaerahan, maupun ikatan keagamaan mereka (Wiloso, 2011). Dibukanya keran akses dan kesamaan kedudukan bagi setiap warga negara tersebut telah menggelontorkan antusiasme kelompok-kelompok minoritas untuk menuntut pengakuan atas identitas mereka.

Sekilas, paham multikultural ini baik untuk semua kalangan. Namun, tidaklah demikian untuk sebagian pihak. Ada pihak-pihak yang tidak sepenuhnya setuju dan bahkan menaruh curiga kepada paham tersebut. Misalnya di Kanada-saat menempatkan bahasa Prancis dan Inggris pada kedudukan yang sama sebagai bahasa nasional, sampai dekade 1970an, warga penutur bahasa Prancis melihat multikulturalisme sebagai taktik warga penutur bahasa Inggris untuk mereduksi penutur bahasa Prancis menjadi sama dengan para imigran (seperti imigran dari Ukraina).

Di Amerika, Ayn Rand (profil dan kiprahnya dapat disimak melalui website: www.aynrand.org), bersama ilmuwan-ilmuwan yang didanainya, berusaha menyebarkan gagasan antimultikulturalisme. Menurut mereka, multikulturalisme yang menekankan diversitas kultural sebagai keutamaan manusia telah menyerang nilai-nilai rasionalitas peradaban Barat modern dengan prinsip-prinsip keutamaan objektivitasnya. Kemudian, sebagian kaum feminis juga mengkhawatirkan paham ini. Mereka menganggap penghormatan berlebihan terhadap partikularitas lokal sangat berpotensi untuk melanggengkan praktikpraktik budaya lokal yang selama ini menyembunyikan tindakan kekerasan atau penindasan terhadap perempuan (Budiman, 2007). Bahkan sebagian pihak yang lain menganggap bahwa paham multikulturalisme ini rentan terjerumus pada isu rasisme dan separatisme budaya.

Sebaik-baik konsepsi tentang multikulturalisme, kita tidak dapat begitu saja mengesampingkan kegelisahan beberapa pihak di atas. Sebab, dalam beberapa praktik pembentukan negara bangsa (nation state) yang mengadopsi paham ini, kesalahkaprahan jamak terjadi. Kymlica (1995: 52), menyebutkan bahwa salah satu kesalahkaprahan tersebut terletak pada konsepsi negara bangsa yang dijadikan sebagai wadah keragaman kultural, di mana agama, etnis, serta bahasa yang beragam digerus melalui program integrasi nasional. Lebih jauh, hal ini berimplikasi pada pembentukan sebuah kebudayaan nasional yang meluruhkan perbedaan kultural antar warga negara. Hal inilah yang perlu dicermati secara hati-hati, yaitu bahwa kelompok-kelompok yang ada dapat memendam gejolak ketidakpahaman mengenai perbedaan.

\section{Multikulturalisme Indonesia}

Wajah kebudayaan Indonesia bila dibangun berdasarkan keberagaman suku, agama, ras dan golongan dapat menunjukkan mimik kebhinekaan apik. Namun, terutama sejak orde sebelum reformasi, tubuh-tidak hanya wajahIndonesia dibakukan oleh giringan rencana pembangunan stabilitas dan kebudayaan nasional yang sentralistik. Hal ini menyeret kultur lokal sekadar menjadi tonggak-tonggak yang seragam. Perbedaan dan penghargaan terhadap keberagaman suku, agama, ras dan golongan tumbang di bawah atap ambisi nasionalisasi. Saat itu, skema multikultural tidak dipakai menjadi pedoman pembangunan negara bangsa ini. Akibatnya, ragam kultur yang notabene adalah kekayaan immateriil tak 
ternilai itu justru sering dijadikan sumber perpecahan dan konflik.

Gejala tersebut seperti menjadi bahaya laten, sekalipun negeri ini telah mendaku reformasi dan demokrasi manjadijalan hidupnya. Ia pun mengalami banyak insiden kekerasan sejak 1998. Mulai dari kekerasan rasial pada 1314 Mei 1998 di Jakarta terhadap etnis Tionghoa; pembersihan etnis Madura di Sambas, Kalimantan Barat pada 1999; konflik di Maluku 2000-2001; darurat sipil di Aceh; dan konflik Muslim-Kristen yang kronis di Poso sejak Desember 1998 (Drajat, 2008). Ditambah konflik baru dalam bingkai-SARA - yang sama yang tak jauh berbeda akhir-akhir ini, seperti terjadi di Sampang, Madura, antara kaum Sunni dan Syah dan di Lampung antara penduduk lokal dan pendatang dari Bali. Maka, demikianlah, harus kita daku pula wajah bopeng multikultural kita saat ini.

Dalam kondisi semacam ini, media di Indonesia tidak tinggal diam. Mereka suka memandang segala sesuatu yang "bopeng-bopeng" sebab nilai beritanya tinggi. Oleh karena itu, mereka pun meliput-, dalihnya. Sebagian mungkin iya, tetapi sebagian yang lain bisa jadi tidaklah demikian. Bolehlah kita ingat, sesaat sebelum Pulau Maluku yang molek itu berubah menjadi medan tempur, satu-satunya koran yang beredar di Ambon hanya Harian Suara Maluku. Para jurnalis Kristen dan Islam bekerja berdampingan dalam keadaan relatif harmonis sekian lama. Namun, eskalasi konflik yang berubah menjadi perang sipil memporak-porandakan hampir seluruh bangunan jiwa dan raga mereka (Hanitzsch, 2004). Kristen berlawan Islam, Harian Suara Maluku berlawan Ambon Ekspres. Tumbanglah tonggaktonggak peradaban nasional itu.

\section{Konflik SARA dalam Bingkai Media}

Konflik berbasis SARA sering dianggap sebagai bahaya laten negara multikultur. Konflik semacam ini sangat potensial terjadi di Indonesia karena sejak lama masyarakat tidak dibiasakan mengenali dan memahami perbedaan. Sebaliknya, selama Orde Baru, kita dilenakan oleh slogan-slogan (propaganda) kedamaian dan kesejahteraan yang menyelinap masuk hingga ke ruang-ruang pribadi kita. Propaganda tersebut tidak mendidik kita untuk mengungkapkan perbedaan. Bahkan, dalam kondisi tertentu kita merasa tabu untuk membicarakannya di muka umum. Maka yang sering muncul dalam forumforum resmi adalah adagium "berbedabeda tetapi tetap satu jua".

Dalam konteks pemupukan rasa satu bangsa, tidak ada yang salah dengan adagium tersebut. Namun bila sosialisasinya justru mengkamuflase perbedaan itu sendiri, seolah-olah perbedaan itu hanya mitos, maka yang terjadi adalah kering dan dangkalnya pengenalan kita terhadap teman, tetangga dan saudara kita yang berbeda etnis, agama, ras, keyakinan dan pandangan. Oleh karena itu, bila ada sedikit saja pemicu yang menghentakkan kesadaran kita akan perbedaan itu, kita kaget bukan kepalang. Kemarahan sepele bisa menyeret perbedaan warna kulit. Persoalan berebut pacar bisa menghadapkan dua kelompok etnis-yang notabene telah lama hidup berdampingan, dalam raut muka garang dengan tangan berhunus pedang dan parang. Kalau sudah begini, lupalah kita akan adagium yang baik itu, atau janganjangan sudah terpleset menjadi "berbedabeda tetapi tetap lawan jua".

Kita pasti mafhum, dalam keadaan konflik dan perang, media berada dalam keadaan yang gamang. Fakta tidak akan 
terlihat seperti biasa. Struktur politik, ekonomi dan sosio-kultural membuatnya berwajah ganda-bahkan multi. Di dalam dunia yang sudah dikuasai oleh orang-orang yang cerdas dan cerdik dalam bermedia (media-savoy world), banyak orang tahu bagaimana membuat dan merajut fakta bagi para jurnalis untuk diliput. Oleh karena itu, sebagian besar pemerintahan suatu negara atau kelompok-kelompok tertentu berpikir bahwa apa yang mereka lakukan dan ucapkan merupakan bagian dari media strategy, yang acapkali berkelindan dengan perputaran roda bisnis mereka (Mcgoldrick dan Lynch, 2001).

\section{Konflik dan Konstruksi Sosial Media}

Menurut Howard (2003), konflik adalah situasi di mana dua atau lebih individu atau kelompok berusaha untuk mengejar tujuan dan memenuhi ambisiambisi yang diyakini tidak bisa dibagikan (share) ke pihak lain.

Konflik tidak melulu berkonotasi kepada kekerasan (violent). Dalam konteks perubahan, konflik adalah sesuatu yang normal. Satu pihak menginginkan perubahan dan yang lain tidak, itu sesuatu yang biasa terjadi. Jika ketidakcocokan itu dikelola dengan damai dan penuh pengertian, konflik bisa menjadi proses yang positif. Namun sebaliknya, ketika ketidakcocokan itu tidak dikelola dengan semestinya, konflik bisa berubah menjadi kekerasan. Ketika ketidakcocokan tersebut sudah bergulir menjadi konflik kekerasan, secara naluriah kita biasanya mengkhawatirkan keselamatan dan memikirkan beribu macam cara supaya kita bisa lolos dari keadaan tersebut. Kekhawatiran dan ketakutan tersebut, sekarang membuat kita, ketika membicarakan konflik, seringkali langsung terhubung dengan kekerasan (Howard, 2003).
Kekerasan sendiri merupakan salah satu dimensi fakta sosial. Dalam bingkai yang sederhana, kekerasan dapat ditengarai dari penggunaan cara fisik dalam menyelesaiakan suatu permasalahan (Siregar, 1999). Penggunaan kekerasan, dalam konteks konflik, menyebabkan ada satu pihak yang mendominasi pihak lain. Pihak yang terkena dominasi biasa kita kenal sebagai korban. Korban adalah person yang kalah atau tidak berdaya manakala berhadapan dengan person lainnya dalam suatu interaksi sosial (Siregar, 2001).

Dalam kondisi seperti di atas, pihak yang mempunyai kekuasaan (politik, ekonomi atau komunal) biasanya mendominasi ruang publik. Apabila timbul konflik, pihak yang lebih berkuasa dapat menggiring wacana ke arah tertentu di mana pihaknya akan dimenangkan oleh makna hasil interpretasi terhadap wacana tersebut. Di sini kita bisa menilai bahwa fakta sosial yang terbentuk di masyarakat tidak semata-mata dapat dimaknai seperti apa yang terlihat dan terdengar. Bisa jadi, dan seringkali, ia adalah hasil dari konstruksi sosial pihakpihak tertentu.

Fenomena ini dapat kita cermati dalam konflik-konflik yang terjadi di Indonesia di mana kelompok yang satu mendominasi kelompok yang lain. Elite politik maupun ekonomi mendominasi pemaknaan "ketidakcocokan" dengan kaum lemah sebagai sesuatu yang sudah selayaknya terjadi dan bisa ditutuptutupi.Kaum yanglemah - yang notabene jauh dari akses terhadap kekuasaan dan pemaknaan wacana melalui media massa, tidak bisa berbuat banyak. Kehidupan di ruang publik tidak berimbang lagi, media yang kritis diangankan dapat mencium "gelagat" ini. Sehingga fakta konflik yang diproses di meja redaksi dan berujung menjadi informasi publik berhasil 
membawa perubahan - sebagai konotasi positif konflik-yang "diamanatkan" oleh konflik itu sendiri.

Kita menjadi mafhum bahwa konflik tidak hanya terjadi di lapangan secara tajam, tetapi juga terjadi dalam ranah wacana alam pikiran publik. Setiap kelompok selalu berinteraksi, saling timpa, tumpang dan tindih memperebutkan dominasi terhadap publik. Media merupakan titik singgung dari perebutan tersebut. Sebab, benyak pihak menyadari bahwa media merupakan sarana yang paling efektif membentukmemori kolektif publik. Siapa yang menguasi media, merekalah yang akan menjadi pemenang dalam pertarungan tersebut (Syahputra, 2006). Oleh karena itu, bagaimana media memberitakan "pertarungan-pertarungan" itu, patut kita telaah lebih lanjut.

\section{Kecenderungan Media Meliput Konflik SARA}

Media tidak berada di ruang kosong. Ia beredar bersama ribuan fakta yang "terkonstruksi" oleh institusi-institusi sosial yang membawa kepentingan masing-masing. Media arus utama di Indonesia tidak lepas dari konglomerasi bisnis yang menggurita. Bila tidak menguntungkan, ia tidak akan dipertahankan. Apabila menguntungkan, dalam kondisi apapun, ia akan diperlebar daya jangkaunya dan diperbanyak. Seperti telah dibuktikan Grup Jawa Post saat mengeluarkan Suara Maluku dan Ambon Ekspres. Keuntungan ini bisa berwujud pemupukan kapital, tetapi juga bisa berwujud perpanjangan pengaruh politik sang empunya. Kita tidak bisa menutup mata bahwa dari segelintir emporium bisnis media di negara kita, sebagiannya sudah berafiliasi dengan kepentingan politik. Hal ini dikhawatirkan akan sangat berpengaruh pada kinerja awak jurnalisme yang menempel di media bersangkutan.

Mengenai hal ini, Katz (1996; Liebes, 1998) menilai bahwa kecenderungan tersebut juga menggejala di Amerika yang liberal dan sebagian negara Eropa yang sangat membanggakan penyiaran publiknya. Gejala mengglobal ketika negara berkembang mengadopsi sistem penyiaran negara maju dan menelan mentah-mentah segala perkembangan teknologi komunikasi yang datang dari Barat. Kehidupan media kita sudah terseret oleh determinasi politik, ekonomi, budaya dan teknologi yang bukan milik kita-tetapi kita daku dengan bangga seolah-olah itu milik "ibu kandung" kita.

Berkait dengan hal itu, kehidupan jurnalisme kita juga bergerak ke arah yang sama. Peliputan di daerah konflik cenderung tendensius dan berorientasi pada elite tertentu. Ini sangat terlihat pada berita dari sebagian besar media saat meliput konflik Aceh (Anto, 2002). Kondisi demikian tidak lagi menempatkan kebenaran-yang notabene sering ditempatkan sebagai prinsip pertama peliputan-sebagai nilai. Tetapi merujuk kepada orang atau kelompok yang merasa membawa klaim-kliam kebenaran tertentu. Hal ini sebenarnya mereduksi salah satu peran media yang diangankan dapat menjadi pengeras suara pihak-pihak yang termarginalkan. Korban konflik Aceh terabaikan.

Selain korban, hal lain yang biasa terabaikan oleh media adalah latar belakang konflik (Pardede, dkk. dalam Anto, 2002). Peristiwa yang berkobar di depan mata wartawan biasanya menjadi patokan utama berita. Sementara itu, halhal yang tidak kasat indera segera tergerus oleh sensasionalisme dan dramatisasi kobaran peristiwa itu. Hal-hal yang ada di balik peristiwa, tetaplah ada pada 
tempatnya. Jurnalis seakan-akan tidak punya waktu lagi untuk menggali dan menelusurinya. Oleh karena itu, beban ini tidak mungkin kita letakkan hanya di pundak jurnalis di lapangan, sebab hal ini sudah masuk ke ranah struktural keredaksian (bahkan keorganisasian secara menyeluruh).

Dalam konteks konflik SARA, seorang jurnalis Bosnia yang menyaksikan peran buruk media dalam mendorong kekejaman perang etnis di negerinya, pernah berujar: "Para jurnalis yang bersembunyi di balik pena dan mikropon, untuk menganjurkan perang, sesungguhnya lebih jahat dari orangorang yang saling bunuh itu sendiri" (Eriyanto, 2003:viii). Seperti hal yang terjadi di Rwanda (1994), provokasi radio pemerintah membuat pertikaian menjadi pennggali kuburan bagi 500.000 anak negeri sendiri. Di Indonesia, media di Ambon telah membuktikan bahwa berita bukan hanya berisi kejelekan pihak lawan tetapi juga saling serang antar media menjadi hal yang biasa (Eriyanto, 2003:34). Hampir tidak ada orientasi ke arah penyesaian konflik.

Apabila peredaran wacana publik sebuah negara sudah dikuasai oleh segelintir konglomerat media dan penguasa politik, maka pemberitaan terhadap konflik pun ada dalam genggaman mereka. Jika publik menghendaki sistem demokrasi tetap menjadi filsafat sosial negara mereka, maka kebutuhan terhadap keberadaan media alternatif menjadi sebuah keniscayaan. Media alternatif ini, di banyak waktu dan tempat, muncul sebagai bentuk perlawanan dan wujud kejenuhan publik terhadap pesan-pesan yang dibawa oleh media arus utama. Sebagai perlawanan karena kesadaran terkuasainya media oleh kaum elite dan sebagai wujud kejenuhan karena paritas berita dan agenda setting yang disetir rating. Media alternatif ini muncul sebagai wujud keprihatinan karena suara akar rumput tersumbat sebelum diteriakkan dan suara kaum menengah perkotaan dianggap dapat mewakili seluruh keragaman Nusantara.

\section{Community Radio}

Sampai tahun 2001 saja, data menunjukkan bahwa ada lebih dari 20.000 stasiun radio di seluruh dunia dan lebih dari dua miliar orang menjadi pendengarnya (Fraser \& Estrada, 2001). Banyak dugaan bahwa radio akan tergerus oleh perkembangan teknologi komunikasi dan informasi, seperti televisi dan internet (dengan World Wide Web-nya). Namun, sampai sekarang kita bisa menyaksikan bahwa radio tetap mengalami perkembangan yang stabil/ konstan. Media ini dapat mengisi hampir seluruh sudut ruang dan waktu planet kita.

Mengenai keungggulan radio dibanding media lain, Fraser \& Estrada (2001) menambahkan: "It is the prime electronic medium of the poor because it leaps the barriers of isolation and illiteracy, and it is the most affordable electronic medium to broadcast and receive in." Karena kemudahan dan kemurahannya, dalam beberapa dekade terakhir, menjamurlah stasiun radio yang dikelola oleh kelompok-kelompok kecil masyarakat yang kemudian lebih dikenal sebagai radio komunitas (community radio). Hal ini ditopang pula oleh iklim politik demokratisasi dan desentralisasi di berbagai belahan dunia; deregulasi media dan melonggarnya monopoli penyiaran oleh institusi pemerintahan; dan ketidakpuasan terhadap kiprah radio komersial.

Carlos A. Arnaldo (dalam Fraser \& Estrada, 2001) memahami radio 
komunitas sebagai: "a social process or event in which members of the community associate together to design programmes and produce and air them, thus taking on the primary role of actors in their own destiny ... the community speaking to each other and acting together for common goals." Ruang lingkup radio komunitas terbatas, baik oleh kekuatan daya pancar (maksimal 50 Watt) maupun radius frekuensinya (maksimal 2,5 kilometer). Ia juga dibatasi oleh kebutuhan kelompok masyarakat kecil tertentu yang hidup di satu kawasan geografis tertentu pula.

Awal kemunculan Radio Komunitas diberbagai belahan dunia mengisyaratkan sebuah perjuangan politik, ekonomi dan sosio-kultural. Maka, bisa dikatakan, ia muncul karena sebuah agenda tertentu. Misalnya, di Bolivia dan Kolumbia (1947), Radio Komunitas berakar pada aktivitas kelompok buruh tambang yang membangun stasiun radio sederhana sebagai medium untuk menyatukan diri dan memperbaiki kondisi pekerjaan mereka. Di Eropa (1960-1970-an), muncul radio ilegal yang mempunyai agenda melawan monopoli pemerintah di dunia penyiaran. Di Afrika, radio komunitas berkembang sebagai alat gerakan sosial, terutama setelahjatuhnya rezim apartheid di Afrika Selatan. Di Asia, UNESCO dan juga beberapa lembaga/organisasi donor internasional lebih banyak mengambil inisistif/terlibat langsung dalam usaha membumikan radio komunitas (Fraser dan Estrada, 2001:6).

Menyimak beberapa contoh di atas, kita bisa mafhum bila sekarang radio Komunitas dapat pula muncul atas dasar agenda politik, ekonomi dan sosio-kultural tertentu. Ada potensi besar radio jenis ini menjadi kuda tunggangan kalangan tertentu untuk tujuan propaganda dan menguasai ruang publik terbatas berdasarkan sentimen-sentimen suku, agama, ras dan golongan tertentu. Pencermatan terhadap potensi ini kiranya harus semakin kuat bila Radio Komunitas yang kelahirannya sedang membuncah ini berada dalam iklim demokratisasi dan desentralisasi serta tumbuh di alam kemajemukan suatu masyarakat.

\section{Radio Komunitas di Indonesia: Potensi Diversity of Conflict(?)}

Proses advokasi Undang-Undang penyiaran pada tahun 2001 adalah pemicu merebaknya Radio Komunitas di Indonesia (Masduki, 2007). Ia menjadi subur dan lebih percaya diri, setelah sebelumnya hanya dianggap sebagai radio liar tak berizin. Pada orde sebelum reformasi, ia diidentifikasikan sebagai radio ilegal, radio gelap, radio perusakpengganggu frekuensi, ataupun radio underground yang selalu dibayangbayangi oleh sweeping aparat. Pemerintah saat itu juga menganggap radio jenis ini memiliki potensi penyebar konflik dan disintegrasi bangsa (bernuansa SARA), sekaligus mendakwanya sebagai pemboros frekuensi (Eddyono, 2012).

Kondisi tersebut, ditambah dengan kiprah radio komersial yang semakin mengecewakan, menjadikan picuan undang-undang tersebut menempati ruang dan waktu yang pas. Radio komunitas kemudian menunjukkan pertumbuhan yang paling signifikan dalam satu dekade terakhir. Konteks pertumbuhan radio komunitas di antara longgarnya dikte pemerintah dan kejenuhan terhadap radio komersial tersebut, dalam bahasa Howell dan Pearce (2001:65-68 dalam Jurriens, 2009), disebut sebagai the "Third Way" alternative medium.

Idealnya, menurut Masduki (2007), Radio Komunitas dapat menjadi wahana milik masyarakat, dari masyarakat, dan oleh masyarakat. Potensi utamanya 
adalah untuk melayani kepentingan masyarakat itu sendiri. Radio komunitas berakar kuat pada pemikiran teoritis demokratisasi penyiaran dan fakta obyektif tidak memadainya peran radio komersial dan radio pemerintah dalam mengagregasi aspirasi warga sipil. Dalam konteks demokratisasi, radio komunitas merupakan derivasi dari konsep diversitas kepemilikan dan penguasaan frekuensi, diversitas bentuk dan isi siaran dan proses lokalisme atau otonomisasi khalayak (Dominick, 2001; dalam Masduki, 2004). Dengan demikian, Radio Komunitas ini seharusnya sarat pula akan aspirasi beragam kultur yang ada di Indonesia.

Semangat penyaluran aspirasi ragam kultur di atas menjadi salah satu dorongan Radio Komunitas "Angkringan" di Yogyakata muncul. Ia tumbuh bersama permasalahan sehari warga desa Timbulharjo, Sewon, Bantul. Permasalahan yang muncul sebagai akibat keprihatinan bersama. Awalnya adalah kumpulan beberapa kelompok warga yang menampung keluhan masyarakat menyangkut ketidakberesan pengelolaan dana pembangunan desa. Korupsi yang diduga dilakukan oleh aparat desa menjadi pokok perbincangan di pertemuan-pertemuan warga tersebut. Namun, aspirasi warga yang dirasa masih parsial dan terkotak-kotak menyebabkan daya tawar kontrol mereka terhadap pemerintah desa kurang optimal. Dari sini, muncullah ide pengemasan aspirasi warga dalam bentuk buletin (antikorupsi). Buletin ini kelak diberi nama "Angkringan". Kian hari pelanggan buletin kian bertambah. Dan distribusi buletin kian sulit menjangkau warga yang tersebar. Maka Radio Komunitas muncul sebagai solusi masalah pendistribusian informasi tersebut sekaligus meniadakan biaya pembelian buletin (Masduki, 2006).
Fenomena Radio Komunitas "Angkringan" tersebut merupakan respons dari kebutuhan mendasar komunitas bersangkutan. Media tersebut muncul karena kebutuhan warga menghendakinya. Dan bukan sebaliknya. Pola yang sama juga terjadi pada pembentukan beberapa Radio Komunitas yang lain. Misalnya Radio Komunitas "Ramanea" di Purwakarta, Jawa Barat, yang bermisi melestarikan budaya dan memantau pelaksanaan proyek pembangunan daerah setempat; Radio Komunitas "Baina" di Cirebon, Jawa Barat, yang mendaku sebagai media informasi seputar permasalahan masyarakat tani; Radio Komunitas "BBM" di Minomartani, Sleman, yang merespons kebutuhan pertukaran informasi seni dan budaya masyarakat; dan Radio "PIBI" di Minahasa, Sulawesi Utara, yang mengampanyekan pemanfaatan sumber energi alternatif (biogas) dari kotoran sapi.

Fenomena kemunculan beragam Radio Komunitas di atas setidaknya telah menggambarkan bahwa informasi yang dipertukarkan oleh media tersebut adalah informasi publik. Bukan informasi tentang kelompok (golongan) tertentu maupun perseorangan. Infomasi publik di sini khusus merujuk pada masalah sebagian besar warga setempat, bukan kelompok tertentu yang mendominasi pewacanaan di suatu wilayah geografis tertentu. Dari situ dapat kita lihat bahwa kecenderungan tumbuhnya Radio Komunitas tersebut seakan tidak memberikan tempat bagi berkembangnya informasi yang didorong oleh arogansi ideologis kelompok-kelompok masyarakat tertentu.

Namun, legitimasi terhadap identitas dan hak-hak kelompok kecil masyarakat akan akses media, tidak menutup kemungkinan akan memunculkan 
dilema atau paradoks. Pengakuan hak terhadap semua komunitas ini dapat memunculkan arogansi subordinasi dan dominasi tertentu terhadap kelompok lain yang "tidak sealiran". Penentangan terhadap kelompok yang tidak sejalan tersebut "diam-diam" atau terangterangan dapat mengudara melalui Radio Komunitas yang mereka bangun. Radio Idza'atul Khoir di Ponorogo, Jawa Timur, mencoba masuk dalam ranah ini. Mereka, menurut sebagian pihak, telah menyebarkan wacana pertentangan antar kelompok masyarakat. Diduga, mereka mempergunakan media radio tersebut untuk kepentingan propaganda aliran tertentu yang ada dalam satu ajaran agama tertentu pula. Hal ini telah mengingkari hakekat Radio Komunitas itu sendiri yang seharusnya bebas dari propaganda dan berakar pada masalahmasalah publik/komunitas, bukan menjadi milik dan berorientasi kepada satu golongan saja.

Hal ini sebenarnya telah mencederai setidaknya dua hal. Pertama, di ruang internal komunitas bersangkutan, kebutuhan anggota komunitas secara umum terabaikan. Individuindividu dalam jangkauan siar radio komunitas tersebut tentunya beragam kebutuhannya, baik jasmani maupun rohani. Tidak bisa dihantam kromo dengan satu aliran dalam ajaran agama tertentu, misalnya (bagaimana dengan individu yang memeluk ajaran lain?). Penguatan kadar intelektual anggota komunitas melalui informasi mengenai masalah-masalah publik (bukan masalah-masalah privat) terabaikan. Pemberdayaan anggota komunitas untuk menjadi lebih kritis terhadap kebijakan publik sama sekali tidak terakomodasi. Lebih jauh, bisa mengarah pada dominasi kelompok tertentu dalam komunitas dan subordinasi kelompok lain di komunitas yang sama. Dalam konteks hubungan wanita dan laki-laki (gender), Ayelt Shactar menyebut kondisi ini sebagai paradox of multiculturalism vulnerability, di mana ia menemukan bahwa pengakuan/ akomodasi multikultural dapat memperkuat kembali power dynamics yang akan melemahkan posisi perempuan (Reich, 2005: 209; Nurkhoiron, 2007: 46).

Kedua, di ruang eksternal, dalam interaksi dengan komunitas lain. Media yang terkuasai oleh kelompok tertentu rentan terhadap isi siaran yang melecehkan atau merendahkan kelompok lain. Hal ini juga tidak luput dari agenda propaganda. Dikotomi "saya" dan "kamu" atau "kami" dan "mereka" akan cenderung mengemuka. Bila hal seperti ini berlangsung melalui Radio Komunitas, maka tidak pelak lagi, perang antar Radio Komunitas dapat berlangsung di kurusetra bumi Nusantara. Dalam kadar dan konteks yang lain, Ambon pernah membuktikan. Tidak hanya dua kelompok masyarakat yang berperang, tetapi media yang telah mereka dominasi pewacanaannya juga ikut berperang; bahkan menjadi senjata ampuh pengobaran api perlawanan.

Arena tanding antar komunitas ini seakan-akan menjadi potensi laten di tengah masyarakat multikultur Indonesia. Dan Radio Komunitas bisa jadi dimanfaatkan untuk mengingkari 'marwah'nya sendiri. Ini adalah paradoks kedua kiprah Radio Komunitas di tengah masyarakat majemuk. Awalnya, ia muncul lantaran terbelahnya tirai sentralisasi di Indonesia. Setiap kelompok yang merasa tertekan di masa itu, hampir secara serentak menyeruak. Suara komunitas yang sebelumnya tidak pernah bisa dikumandangkan di media sekecil apapun, berkokok dengan lantangnya. Mereka membawa identitas masing-masing sebab pengakuan 
terhadap hal tersebut semakin nyata. Tuntutan terhadap persamaan hak komunitas, yang paling minor sekalipun, semakin mengemuka.

Ia menjadi paradoks ketika keunggulan budaya mereka membutakan pemahaman mereka terhadap perbedaan yang sebelumnya memang sudah dipahamkan sebagai keseragaman. Hal ini dapat berkembang menjadi kesombongan identitas kultural. Hal-hal yang berhubungan dengan pihak lain atau berseberangan dengan identitas mereka menjadi bahan pembanding aktualisasi keunggulan identitas kelompok sendiri. Dalam konteks kehidupan bermedia, diversity of content yang digadang-gadang dapat semakin menguat, bisa berubah menjadi potensi diversity of conflict. Karena ada 1001 alasan untuk menunjukkan perbedaan/perbandingan keunggulan indentitas kultural masing-masing kelompok, bila kebutuhan komunitas yang sebenarnya tereduksi oleh dominasi satu kelompok. Atau bila satu kelompok tertentu telah memanfaatkan gelombang frekuensi-yang notebene adalah milik publik-untuk kepentingan mereka 'pribadi'. Hal ini tentu tak luput dari penegakan undang-undang penyiaran (termasuk dalam hal perizinan) yang masih gamang.

\section{Simpulan}

Arus deras demokratisasi penyiaran di Indonesia tidak serta merta dapat menjamin diversity of content dan diversity of ownership di ranah empiris. Radio Komunitas yang muncul sebagai salah satu senjata utama implementasi kedua prinsip diversitas itu ternyata tidak luput dari potensi penjungkirbalikan prinsip-prinsip itu sendiri. Potensi itu dapat masuk melalui pemanfaatan isi media tersebut sebagai alat propaganda kelompok tertentu (message). Dapat pula dari sisi kepemilikan yang sama sekali tidak merepresentasikan komunitas yang dirujuk-yang idealnya menjadi owner dan sekaligus orientasi penyiarannya (communicator).

Bila pada orde sebelum reformasi konflik vertikal lebih berpotensi terjadi, maka dalam iklim desentralisasi ini, konflik horizontal terus menghantui. Oleh karena itu, kita mungkin menjadi mafhum bila media komunitas ini masih menjadi bahan tarik-menarik dan diskusi beragam kepentingan-sebelum revisi undangundang penyiaran yang baru dibentuk; seiring dengan multikulturalisme yang masih diperdebatkan makna dan implikasinya hingga kini.

\section{Daftar Pustaka}

Anto, J. (2002). Luka Aceh, Duka Pers. Medan: KIPPAS.

Budiman, Hikmat. Hak Minoritas: Dilema Multikulturalisme di Indonesia. Jakarta: Yayasan Interseksi.

Drajat, Dede (2008). Jurnalisme Damai versus Jurnalisme Kekerasan. Jurnal Kommti. Volume 2, Number 4.

Eddyono, Aryo Subarkah (2012). Radio Komunitas dan Kegagalannya Sebagai Media Counter Hegemony: Studi Kasus Pada Radio Panagati dan Angkringan di Yogyakarta. Journal Communication Spectrum, Vol. 2 No. 2. Februari-Juli 2012.

Eriyanto (2003. Media dan Konflik Ambon. Jakarta: Kantor Berita $68 \mathrm{H}$.

Fraser, Collin \& Sonia Restrepo Estrada (2001). Community Radio Handbook. UNESCO.

Hanitzsch, Thomas (2004). Journalists as Peacekeeping Force? Peace Journalism and Mass Communication Theory. Journal of Journalism Studies. Volume 5, Number 4. Routledge.

Howard, Ross (2003). Conflict Sensitive 
Journalism. Impacs and International Media Support.

Jurriens, Edwin (2009). From Monologue to Dialogue: Radio and Reform in Indonesia. Leiden: KITLV Press.

Kymlicka, Will. 1995. Milticultural Citizenship: A Liberal Theory of Minority Rights. New York: Oxford University Press.

Liebes, Tamar dan James Curran. 1998. Media, Ritual and Identity.. London, New York: Routledge.

Masduki (2007). Radio Komunitas: Belajar dari Lapangan. Jakarta: Bank Dunia.

McGoldrick, Annabel \& Jake Lynch (2001). What is Peace Journalism. In From Headlines to Front Lines: Media and Peacebuilding. The Quarterly Journal of IMPACS, The Institute for Media, Policy and Civil Society. Winter 2001.

Nurkhoiron, M., Marshudi Noorsalim dan Ridwan Al-Makassaray. Hak Minoritas: Multikulturalisme dan Dilema Negara Bangsa. Jakarta: Yayasan Interseksi.

Parekh, Bhikhu. 2000. Rethinking Multiculturalism: Cultural Diversity and Political Theory. London: MacMillan Press Ltd.

Siregar, Ashadi (1999). Berita Kekerasan di Media Massa. Disampaikan pada Seminar Kekerasan Dalam Masyarakat, Pemberitaan Media Seputar Kekerasan Dan Kekerasan Oleh Media Massa. Lembaga Studi Informasi dan Media Massa (eLSIM). Makassar 25 - 26 November 1999. Diunduh dari www.ashadisiregar.wordpress.com Januari 2013.

Siregar, Ashadi (2001). Jurnalisme Perdamaian, Resolusi Konflik Sosial". Makalah Seminar Pers Menyikapi Konflik Kekuasaan, Lembaga Studi Perubahan Sosial (LSPS). Surabaya, 8 Februari 2001. Diunduh dari www.ashadisiregar. wordpress.com Januari 2013.

Siregar, Ashadi (2013). Mengeritisi
Kecenderungan Pemberitaan Konflik Pada Media Pers di Indonesia. Makalah disampaikan pada Seminar Resolusi Konflik Melalui Jurnalisme Damai, Yayasan Informasi Pendidikan dan Penerbitan Sumatera (KIPPAS), Medan 19 April 2001. Diunduh dari www.ashadisiregar.wordpress.com Januari 2013.

Syahputra, Iswandi (2006). Jurnalisme Damai: Meretas Ideologi Peliputan di Area Konflik. Yogyakarta: Pilar.

Wiloso, Pamerdi Giri (2011). Multikulturalisme dalam Perspektif Antropologi. Makalah Seminar Multikulturalisme dan Integrasi Bangsa yang diselenggarakan oleh Kementerian Kebudayaan dan Pariwisata, Dinas Pemuda, Olahraga, Kebudayaan dan Pariwisata Kebupaten Semarang. Tanggal 7 Juli 2011. Di Kebon Raja, Jl. SoekarnoHatta Km. 25, Karangjati, Ungaran.

Situs:

h t t p : / / w w w .india-s em in a r. com/1999/484/484\%20parekh.htm. Diakses Januari 2013.

www.aynrand.org. Diakses Januari 2013. http://www.seputar-indonesia.com/ edisicetak/content/view/431904/. Diakses tanggal 22 Januari 2013.

"What is Multiculturalism?" melalui http://www.india-seminar. com/1999/484/484\%20 parekh.htm. Diakses tanggal 23 Januari 2013.

Saiful Bakhtiar. "Petani pun Punya Radio". Melalui http://kombinasi. net/petani-pun-punya-radio/ diakses tanggal 9 April 2013.

http://balaibudayaminomartani. wordpress.com/2011/01/26/helloworld/ diakses tanggal 9 April 2013.

"PIBI FM, Radio Komunitas untuk Pelestarian Lingkungan" melalui http://regional.kompas.com/ read/2012/09/17/09405934/ diakses tanggal 9 April 2013. 